\title{
Response of pea (Pisum sativum L.) to Rhizobium inoculation and nitrogen application in soils of North East alluvial plains of Bihar
}

\section{AJEET KUMAR AND DIWAKAR PASWAN}

Received : 26.06.2015; Revised : 27.10.2015; Accepted : 12.11 .2015

\section{MEMBERS OF RESEARCH FORUM:}

Corresponding author : AJEET KUMAR, Regional Research Station, Madhopur, WEST CHAMPARAN (BIHAR) INDIA Email: ajeetrau@gmail.com

\footnotetext{
Co-authors :
}

DIWAKAR PASWAN, Regional

Research Station (R.R.S.), Agwanpur, SAHARSA (BIHAR) INDIA

\section{Summary}

Among legumes, pea (Pisum sativum L.) is the second most important legume, which is widely used both in human nutrition and as fodder. Currently, pre-sowing inoculation of pea seeds is a promising treatment and is one of agronomic solutions for sustainable agriculture. As per the objective of the research, to determine the effects of Rhizobium inoculation and different levels of nitrogen on the yield potential and growth attributes of pea, the research was conducted in Split Plot Design with 3 replications, at Research farm of RRS, Agwanpur, Saharsa. Nitrogen application had significant effect on the plant height, number of branches, root and shoot dry weight, number of nodules, seed yield, biomass yield, harvest index, number of pods, as well as crude protein rate of seeds in both years. Plant height, number of pods, harvest index, number of nodules, crude protein rate and root dry weight were higher with application of $20 \mathrm{~kg} \mathrm{~N} \mathrm{ha}^{-1}$ while seed yield, shoot dry weight and number of branches were higher with application of $60 \mathrm{~kg} \mathrm{~N} \mathrm{ha}^{-1}$, in the 2 seasons. The lowest values related to these parameters were obtained from the control treatment. Inoculation treatment had also significant effect on the all parameters investigated in both the years. The highest values regarding these parameters were obtained from inoculated plants, whereas the lowest values were obtained from the un-inoculated plants. Interactions of nitrogen and inoculation had significant effects on the all parameters investigated, except for number of nodules in 20092010 and crude protein rate of seeds in both years. The highest seed yield was obtained under treatment $20 \mathrm{~kg} \mathrm{~N} \mathrm{ha}^{-1}+$ inoculation with 1654.3 and $1625.0 \mathrm{~kg} \mathrm{ha}^{-1}$ in 2009-10 and 2010-11, respectively.

Key words : Pea, Rhizobium, Nitrogen, Nodulation, Yield

How to cite this article : Kumar, Ajeet and Paswan, Diwakar (2015). Response of pea (Pisum sativum L.) to Rhizobium inoculation and nitrogen application in soils of North East alluvial plains of Bihar. Asian J. Soil Sci., 10(2) : 252-258. 